\title{
States of conflict and the idea of pacifism in the novel Fratricides
}

\author{
Amalia-Florentina Drăgulănescu \\ Department of Literary History, A. Philippide Institute of Romanian Philology, Romanian Academy, Iaşi, Romania
}

Email address:

amalita004@yahoo.com

\section{To cite this article:}

Amalia-Florentina Drăgulănescu. States of Conflict and the Idea of Pacifism in the Novel Fratricides. International Journal of Literature and Arts. Special Issue: Discourses of Militarization and Identity: Literature of Conflict. Vol. 2, No. 6-1, 2014, pp. 30-34.

doi: 10.11648/j.ijla.s.2014020601.15

\begin{abstract}
Father Ianaros, the main character of Nikos Kazantzakis' Fratricides is leading a two-way battle, a real conflict with himself as well as the struggle between body and soul, torn between fascists and communists. The confusion between red and black, between life and death (bodily and spiritual) and its source that rests in the peace without peace that the priest confronts in his questions is often made. If the war of the soul with the body remains, somehow, always on the same line, the contradiction between yes and no, between $N a i$ and $\mathrm{Ohi}$ (Gk.) multiplies (but having in common the priest's consciousness of Castelos), knowing several directions possibilities: the fellowship either with the red, or the black side; the isolation from the real world; abdicating from the condition of priest as the angel of God on earth. Like Jesus, pushed up and down by the wave of doubt, the father of the village lies at the crossroads between various judgments, set out to find the truth in the wilderness of questions. Much of the agony is his struggling with loneliness, under the monos position before a herd ravaged by civil war. The dilemma is amplified, tripled, and the choice is complicated. Therefore, at Nikos Kazantzakis, the necessarily provided Pascalian condition of man, half zoon, half angel comes to be higher, the demands made on man actually referring only to his angelic, superhuman nature, hardly allowing the pacification.
\end{abstract}

Keywords: Conflict, Priest, Pacifism, Self, Actual Patterns

\section{Introduction}

Once it is known, that the term conflict comes from the Latin verb confligo, -ere $=$ to fight, to beat each other, with the noun participle phrase of conflictus, with meanings clash, shock and strife, fighting against someone. Several dictionaries define the conflict through similar terms as violence, dissension, friction, dispute, quarrel, scandal, fight, war.

Look how the conflict arises in two reference dictionaries: Mic dicţionar enciclopedic român and Webster's New World Dictionary. Keeping a very broad definition of the term conflict, close to the etymon and the current meaning, the Romanian dictionary states the meanings of: "misunderstanding, clash of interests, disagreement; antagonism; strife, violent discussion" [1]. More analytic, the American dictionary deepens the definition of what it generally appoints as "a disagreement or an acute clash of interests, ideas, etc., which refers to the process rather than the outcome" - for which synonyms as fighting or any other general word denoting fight (physical), struggle (e.g. the struggle for existence), quarrel (verbally) or competition (struggle for supremacy in a certain matter). The lexicon captures several facets of the conflict in its present acknowledgement: 1 . fight or battle; war; 2. disagreement or sharp opposition of ideas, interests etc; noisy quarrel; 3 . emotional disorder caused by a strong argument, and contrary impulses or inability to reconcile the impulses with realistic or moral principles. 4. it is rarely stated, it is also used with reference to the collision of bodies in motion [2].

A more recent, Romanian-Neo-Greek, Neo-Greek-Romanian dictionary takes into consideration

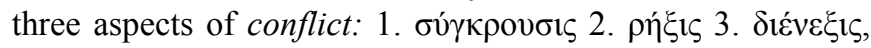
noting so that, paradoxically, the first sense of the term contains the particle $\sigma v v=$ "together with" the second meaning is more serious, involving a challenge, a discord, disunity, and the third being more evolved, a little neological controversy, dispute. 
Because of the darker theme, however, the best word to the realities of the tragic novel by Nikos Kazantzakis, Fratricides and perhaps the least liked by readers of this prose writer

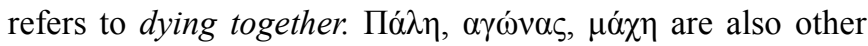
nouns that further define the fierce fighting of this Cretan author's writing. In a context of proximity, this easy allegorical novel is the most politicized in the sense of policy infusion, of Kazantzakis' writings. If Politeia is originally multifaceted, being rather used in the sense of civility, today two definitions frequently occur being used in political science by Harold D. Lasswel, Who, what, when and how is takes (1936) - David Easton, An Approach to the Analysis of Political Systems (1957). (Wikipedia)

\section{Warfare Context}

To properly understand the content of the novel $O i$ adelfophades we must first understand the events that took place in the Greek civil war (1946-1949), at the end of the World War II whose grave consequences would be felt more years thereafter. The fierce fighting between communists and anticommunists resulted in over 100,000 deaths and thousands of refugees, some of them (especially children between 3 and 14 years) reaching under the pressure of these events, in Romania, too. The setting takes place in Castelos, a real or imagined fortress, where the two opposing powers will face. However, at first, almost nothing anticipates the force that will face the red and black side: "The sun was rising over Castelos. It flooded the rooftops in waves, flowing on the peripheral, narrow and sloping streets, roughly revealing the ruthless ugliness of the village" (p. 9) Two features strike on from the beginning the overall perception: the fact that the antagonistic vision and the exaggerated simplicity evokes on the one hand, the clashes in the ancient theaters, and also the similarity of this prose with Kazantzakis' plays rather than his other novels. The Fratricides, like all Kazantzakis' work bears the fundamental dilemmas of our age, the truth being paradoxically expressed: the asceticism and frenzy sensory temptation, faith and vain hope, pride and humility, compassion for the man lost in the great Cosmos, rebellion, fascination of masses and revolution, having the presentiment of the horrors to come". [3]

Moreover, "His theatrical plays are not plays, his poetry is not poetry, his philosophy is not philosophy, his novels depict no novelistic discourse and only his travels are true evidence of good journalism. So, a good journalist; is that all he is?" [4]. Some premonitory signals gradually induce the subsequent atmosphere of the aforementioned novel: "Their life is a continual struggle with God, with the wind, snow, death. This is why people of Castelos were not surprised when the massacre began when brother rose against brother." (p.16). The writing which we refer to is a book mainly about the relationship between identity and otherness, but unfortunately more about the specific difference rather than the proximal area of this concept.

\section{Identity and Otherness in Fratricides}

In this difficult and misty context "A single man stands among them without weapons and without bad faith, with his bare hands outstretched: Father Ianaros, the village priest. He stood alone and looked either left or right, not knowing where to go, always asking the same painful question: "If Jesus Christ would descend on Earth, whose side would He be? The black or the red side? Or He would stand between them with His outstretched hands, crying "Unite, brothers! Unite, brothers!" (p.17). Intruding the idea of Politeia, which we initially mentioned is maintained until the end, but this time in reverse, meaning that the model of kingdom of heaven to be established in the middle of the major conflict that takes place between the two sides. We must emphasize also the ambivalent name of Lord's servant, Ianaros (the Cretan character of Toda-Raba as well, by the same author, is called Gheranos, using the metathesis), a name that leads to the old deity Janus bifrons, depicted with two antagonistic faces, one of which looked forward and the other backward; the god of gates, celebrations, rites of passage and transition phenomena. (This proper name and the name of January relate to yanah in Sanskrit, meaning the way). Moreover, the plot takes place in Holy Week, the reconciliation of the two sides representing at a virtual level, an occasion for another imitatio Hristi. However, there are many previous indications that this reconciliation attempt will be doomed to failure, because the majority is against him: "They shout hard, but they all passed him, red or black, and they cried, mocking him: "Bulgarian! Traitor! Bolshevik! / Vagabond! Fascist! Bastard!” (p.17)

The temporal circumstances are important in the order of action because the anticipation of Christ's Resurrection outlines a possible overcoming of the initial conflicts of that place, which not coincidentally is dedicated to Saint Constantine ("the fire keeper"), and they overlap anastenaria a feast, rather controversial today, having a pagan substrate of the Balkan area, ennobled in part by Christian elements, the (re) resurrection of nature and man, in a broad and narrow sense. In this context, the initiates went barefoot over hot coals in a purification ritual, of invigorating the twinning of powers above all. If we return again to the features of Janus, we find that they are: Divum Pater (Father of the gods), Consivius (the masculine counterpart of Consiva, the epithet of the goddess Ops, the abundance, the pair of Saturn, the god of golden age; the verb is consero, meaning to sow, to throw the seed in the furrow, to fill, hence the idea of breeding, prosperity and abundance) Patultius, i.e. the Starter (from the verb Pateo, to be opened) Cerus, that he who does grow and bear (masculine of Ceres, goddess of grain, whose name derives from the verb creo, to increase, hence the idea of fruitfulness and fertility) and Duonus, the benefactor. Some of these metaphorical signs are in possession of the main character, Father Ianaros who is speaking, from the outset, with himself: "Can man overcome his human condition? Father Ianaros wondered himself. He answered: "Sure, he can! He can, but only for an hour or two, just for a day, no more. This is the meaning of eternity and the Divine Fire, which people call it, Paradise" 
(p.18) In his early memories, the priest slowly slid towards the image of the seven brothers who formed a group bearing the sacred name of anastenarids. He himself was their captain, being arhanastenarid ("The Anastenarids came in haste, one after another, Father Ianaros stretched forward was the head of the procession and sang love songs dedicated to Death watching the Gate of eternity, ready to open it at any time" (p.19). Here it should be mentioned that even Plutarch himself, in Parallel Lives said that "There is a temple of Janus in Rome with two gates, which the Romans call the War Gate because it was believed that it was open in times of war and closed during peace".

\section{Conflict State of Mind}

The protagonist of Fratricides is constantly in a state of conflict with the self, a fight like this, two-way, with himself, as well as the struggle between body and soul, hardly becoming the man of God, torn between fascists and communists: "Forgive, O Lord, he whispered, forgive them both slain and killers, but you would better send fire upon us, so as not hear Your name as a reproach" (p. 20). Even the symbols, and imagery has negative connotations when the hatred between the two groups is felt over the whole village of Castelos, and when the bishops Damianos and Ianaros, the locals decide to send it elsewhere, starting in a kind of exodus, but at a smaller scale ("They stopped for a moment to say goodbye to the image of Pantocrator, which was dominating from the dome. (...) For the first time he saw his wild eyes, his lips with anger and contempt and how he was holding the Bible like a rock that was about to toss it in people's heads" (p.21).

The mentioned novel is also the most thesist prose of Kazantzakis, is a novel of ideas, the action is not fully cohesive and the storyline is likely to fall apart at any moment. However, the only character who shows consistency is Father Ianaros, the shepherd and the representative of Lord on earth, seeking a solution of reconciliation between combatants. There is therefore in the novel outside conflicts, but there is also the inner conflict of the priest's soul. However surprising may seem, people do not like to be inconsistent. If there is a conflict between what they believe and what they do, it feels kind of discomfort, which is the result of an inner mechanism called cognitive dissonance - that is, the occurrence of an inner conflict. This means a conflict because a person simultaneously possesses two opinions which do not only support one another but they are also sometimes exclusive.

Occasionally, some items that bring back some hope in the hearts of the villagers are felt, but fail to make enough room, neither stylistically within the contents of the facts: "They danced slowly for a while, silently when suddenly they saw the rainbow - green, red, gold, thrown across the sky, touching the earth at the ends. "It's a good sign, brethren", cried Father Ianaros. "It's Virgin's girdle and it was sent to give us courage and protect us." (p.23). Other cues, details that are lost in the multitude of its original details, this time about the personal life of the parent who encourages people refer to the following:
"He was standing in the middle of the road and thought; he was alone, his wife died, his son - his only son - had left home years ago and wandered from one harbor to another, he was losing his time crossing seas as a smuggler or captain of the boat." (p.25). The metaphorical allusion to the prodigal or wasteful son will come back another time, but for now the ordinary reader tends to lose sight of it.

The inner monologue is absolutely pervasive, and this enhances those thoughts that disturb the Father, but this is also a self-encouragement, because he still oscillates between fear and love of a God and people «Well, Father Ianaros, let's see what you're molded - of courage or mud?" He then said to himself "Stand up and move on! Go and let the way to take you where it will. Allow yourself to God's will, He knows what he wants!" He walked three days» (p.25) However, the monologue opens to an attempt of dialogicity as Umberto Eco understands it when he explains openness as "an open situation, in movement. A work in progress", which he understands as "the possibility of numerous different personal interventions" [5], that are, however, guided by the intentions of the author. The interpreter or the performer participates in completing an unfinished work: "the author offers the interpreter, the performer, the addressee a work to be completed” (ibid). „Moreover, openness can be found in Kazantzakis' novel in the way the centripetal and centrifugal forces that are responsible for forming identity exist in an ongoing tension that is never finally resolved" [6].

Trying to dialogue with people is somehow activated when Father Ianaros understands his own mission, and wants to take her to the end, because, he says: "I wanted to be placed at the foundation of a building next to stones". The conflict with himself is increasing on the other hand, in the sense that the vision of creative destruction, called the great collapse in the famous novel The Life and Adventures of Alexis Zorbas, catch germs in almost the perpetual rebellion of the central character: "What is your problem with the world Father Ianaros that you want to cast the fire on it?" "It's the devil's work! It was sometime created by God, but now it is no more." (p.30). Between uprising and resignation, the father of Castelos deliberately chooses the former, and he assumes, in a Luciferic primordial way wanting to establish a completely new human model, thus triggering a series of conflicts, as I mentioned, inside and outside him. But, somehow, from uprising to revival is not too far away, and here the model of deity, of Christ precisely, is more than eloquent.

"Rise the Groom's star in the night" Father Ianaros was singing in high voice, meeting the Savior who was getting caught, smiling bitterly, in the net of the venomous spider rightly woven by people" (p.33). This is an essential, enlightening fragment belonging to the initial chapters that properly illustrate the antinomies produced by the desperate attempt of man stepping over his own shadow, that of overcoming the human condition, having Christ as intermediate. Between the marvelous metaphor of the Groom who is preparing for the wedding, of the man who enters a superior state (stasis) and the opposite image of the Lord, of the Creator who is surprised within the warps of his own 
creatures, is a discrepancy and also a subtle association that the reader always remain subdued. The dynamics of such stylistic fragments consists in a concealed, sometimes hermetic carrying, of some older elements, being related to the ancient hubris, but also in the transfiguration of others, regarding for instance the genius creator drama as it was once evoked in the Balkan area through the legend of Master Manole, of the bridge of Arta, over the River Arachtos as well as of the specific Romanian ballad, of the pastor of Miorițal The Ewe.

Beside Father Ianaros, who is mostly part of the volume, which leads us to believe that the "fratricides" are actually his doubts in his heart, Greece is itself a character that envelops with its spectrum the whole action, grounded, however, by powerful conflicts. Extremely moments of self and world peace rare occur, and these are reflected in micro-fragments of the following type: "Father Ianaros softly humming a song, heading for the church"; "I call God everything, Father Ianaros added and smiled" (pp.42-43). But most often, especially in the second part of the novel awful images come to life from the Greek writer Kazantzakis - smoldering ruins, poverty, misery, hunger, stones sprinkled with blood, carrion devoured by jackals and vultures. Here, Balkanism, in the sense of perpetual duality, makes room and "aims at dominant mentalities in the southeastern Europe, especially a behavior no moral principles, corrupt, perverted, versatile and transactional, and not only at the individual, directly interpersonal level, but also at the administrative-institutional, social and political" [7]. Thus, the monks' imaginary who are multiplying and falsifying holy relics as the Virgin's girdle, simultaneously presenting it as original in several places, or the skull of St. Cyriacus in several stages of life (child, adult, etc.) become bitterly comic.

The fact is that this exceptional prose cannot be told in itself, it is fragmentaristic, such enrolling in modern patterns. The main paradox is that the fight (conflict) is held in the name of freedom, where justice seeks foothold on both sides. Between these two camps, the two devils that rip Greece, seeing his brothers killing without mercy and without remorse, Father Ianaros fights himself, being animated by his faith in God for their reconciliation, for peace and love. The character is so great through his the force of mind that leads him over the ravine steep of Greece to fulfill a sacred duty. In most cases, Father Ianaros stirs admiration within the prevented souls, and yet he does not manage to tame some of them. Elements of numerology, implicitly included in the book (the seven days of the week before Resurrection, converted to some extent in the related chapters) complement the symbolism of the volume pursuing the ultimate goal, the collapse of the conflict, figures 8 and 9 , the vertically symbol of infinity, and the symbol of eternity, stylistically building the mystery of the unexpected final outcome, rather than tragic: "The old man heard the call and returned. The bloody red beard was glowing in the sunlight. Loucas set aside his companions, fixing the arm rightly on his shoulder. The bullet hit Father Ianaros right in the forehead. The old man widely opened his arms, and without even to gasp he fell face down over the rocks." (p.267).
It is obvious that the opening I was previously talking about is omnipresent, even in the final gestures of God's servant, Ianaros.

A special character, also conflicting, though less present is Father Ianaros' son, who became captain of the rebels in the mountains - ruthless, cruel, devoted to the cause, and his pride, sometimes even against his own conscience. In his soul a fierce battle is given, as hard as that between the two camps where the Greeks are divided - the communist ideal and the ideal personal, his hatred for the father who chastised him in childhood, but also the admiration towards the powerful nature of the same father; the love and hatred inside his soul forge his unpredictable, wild, fearless soul. Signs of humanity are extremely rare in this book - Vassos soldier lets a prisoner of the opposite camp to escape; the father of the village tries to give food to a child who was eating clay. All these are reflected in the images and figures of speech loaded with hope, such as the following quote: "God's will is like an orange tree, he was thinking of him and his eyes filled with tears, a tree whose fruit are only flame and sweetness! What a joy, what an inviting flavor, how much peace! And the blue-green, wild sea was shining among the loaded orange trees."[8]. Long ago, the nearly "crazy priest of Christ" states that he took refuge from the world in a kind of cocoon silkworm (leitmotiv that is present in the Report to Greco, as well), and that it has a roll that shows the sky.

The particular themes of Kazantzakis' prose novel merges during Fratricides with over-measure - absolute freedom, the human essence soluble in the divine, propensity for religion as a link between transcendence and immanence, the assumed individual choices and the positive individualism, all these intersecting and sometimes being in creative type conflict in an effervescence of the spirit as it seldom existed. In Kazantzakis' artistic speech echoes the understanding and tolerance towards all that is human, to the implacable destiny of every human being, but above all, to the person invested with divine attributes, who gave up persona, or the Ancient mask. Contradictions, doubts, smoldering and then unleashed conflicts, true patterns - justice, freedom, divinity: they are all coordinates that make up this historical tragic descent of the modern Greece. Ianaros wants to set the paradigm of love, of absolute peace, of the desired normality, is that one who must restore the balance badly shaken. On the ground of those harsh times, the scattered spirit both in Father Ianaros and in his son, Captain Dracos, found the best suited essence to knead this novel of such narrative density and with such a complex emotional register.

\section{Conclusions}

For some, Fratricides of Nikos Kazantzakis may seem an obsolete writing; it is, however, a deep, visionary novel, that from the communists and fascists rebels' fighting of the last century Greece and until today's guerrilla clashes in Afghanistan, Pakistan etc. the patterns have changed and not quite... In 1946, the writer appealed to the spiritual world leaders (not technocrats, not politicians, not economists), 
whose responsibility is always a permanent act to mobilize to discover which is the duty of the contemporary man to restore harmony and retrieve the moral resources of the universe. In this regard, his prose is of a sharp vividness, and offers a panoramic view of the whole world contemporary issues.

Finally, the conflict state of self with the world, of the man with his peers, of the person with the divine does not necessarily imply a bad thing, it somewhat resembles that of the Garden of Gethsemane; what is the most important is the solving, pacification, final beatitude, and especially the attempt to restore good in the world, because even Christ said: "I have not come to the world to bring peace, but sword!"

\section{References}

[1] Mic dicţionar enciclopedic, Bucureşti: Editura Ştiinţifică şi Enciclopedică, 1978, p. 227.
[2] David B. Curalnik Webster's New World Dictionary of the American Language, Second College Edition, New York: Prentice Hall Press, 1986, p. 298.

[3] Alexandra Medrea-Danciu, in Preface to Fratricides, Timişoara: Editura de Vest, 1993, p. 10.

[4] George Theotokas, Diary Notebooks 1939-1954, Athens: Estia, 1987, pp. 573-574.

[5] Umberto Eco, Opera aperta, Milano: Bompiani, 1962, p. 19.

[6] Charitini Christodoulou, Dialogic Openness in Nikos Kazantzakis, Cambridge: Cambridge Scholars Publishing, 2012, p.12.

[7] Dicționarul General al Literaturii Române, vol. A-B, Bucureşti: Editura Univers Enciclopedic, 2004, p.328.

[8] Nikos Kazantzakis. Fratricides, Timişoara: Editura de Vest, 1993, p.60. 